Diunggah : November 2020

Diterima : Desember 2020

Dipublikasi : Desember 2020

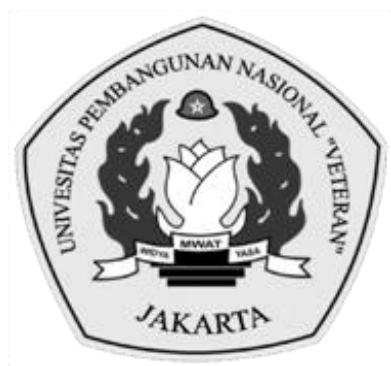

\title{
PERSEPSI KEMANFAATAN DAN KEMUDAHAN WAJIB PAJAK DALAM MEMBAYAR PBB MENGGUNAKAN GO-PAY
}

\author{
Anita Primastiwi ${ }^{1}$, Dewi Kusuma Wardani ${ }^{2}$, dan Hermalia Hermalia ${ }^{3 *}$ \\ 1anita.primas@ustjogja.ac.id, 22dewifeust@gmail.com, 3h3rmalia@gmail.com \\ 1,2,3Universitas Sarjanawiyata Tamansiswa, Indonesia \\ *Penulis Korespondensi
}

\begin{abstract}
Abstrak
Penelitian ini bertujuan untuk menguji apakah persepsi kemanfaatan dan persepsi kemudahan mempengaruhi minat wajib pajak dalam membayar Pajak Bumi dan Bangunan (PBB) menggunakan Go-Pay. Metode pada penelitian ini menggunakan metode deskripsi kuantitatif dan data primer dengan menggunakan kuesioner. Penelitian mengambil sampel 87 responden pengguna Go-Pay dan merupakan Wajib Pajak Bumi dan Bangunan di Kabupaten Sleman. Hasil dari penelitian ini menunjukkan bahwa persepsi kemanfaatan berpengaruh positif terhadap minat membayar PBB menggunakan Go-Pay. Hal ini disebabkan adanya manfaat yang dirasa wajib pajak seperti tidak perlu mendatangi kantor pajak sehingga wajib pajak tertarik untuk membayar PBB melalui Go-Pay. Selain itu, persepsi kemudahan berpengaruh positif terhadap minat membayar PBB menggunakan Go-Pay. Hal ini disebabkan wajib pajak merasakan Go-Pay mudah digunakan, mudah dioperasikan, dan mudah dipahami sehingga wajib pajak tertarik untuk membayar PBB melalui Go-Pay.
\end{abstract}

Kata Kunci: Persepsi Kemanfaatan; Persepsi Kemudahan; Pajak Bumi dan Bangunan; Go-Pay

\begin{abstract}
This study aims to test whether the perceived usefulness and perceived convenience affect the interest in paying Land and Building Taxes (PBB) using Go-Pay. The method in this study uses quantitative description methods and primary data using a questionnaire. The study took a sample of 87 respondents who use Go-Pay and are PBB taxpayers in Sleman Regency. The results of this study indicate that perceived usefulness has a positive effect on interest in paying PBB using Go-Pay. This is due to the perceived benefits that taxpayers feel, such as not having to go to the tax office so that taxpayers are interested in paying PBB through Go-Pay. The perception of convenience has a positive effect on the interest in paying PBB using Go-Pay. This is because taxpayers find Go-Pay easy to use, easy to operate and easy to understand so that taxpayers are interested in paying PBB through GoPay.
\end{abstract}

Kata Kunci: Perception of Benefit; Perception of Ease; Land and Building Tax; Go-Pay

\section{PENDAHULUAN}

\section{Latar Belakang}

Pada masa pandemi Covid 19 saat ini, dimana virus tersebut bisa menyebar melalui kontak langsung maupun tidak langsung dengan penderita, tentu saja menimbulkan pemikiran agar pada masa yang akan datang masyarakat sebagai wajib pajak dapat membayarkan pajaknya tanpa harus mendatangi kantor 
pelayanan pajak dan bertemu dengan banyak orang. Ini tentu saja sebagai upaya agar kemungkinan suatu virus atau penyakit untuk semakin menyebar luas dapat diminimalisir. Cara yang dapat dilakukan adalah dengan mengadopsi teknologi untuk melakukan pembayaran pajak secara online. Hal ini selaras dengan kemajuan teknologi yang saat ini sudah memasuki era revolusi industri 4.0, dimana salah satu perkembangannya adalah semua kegiatan pembayaran mengarah pada pembayaran online yang bersifat cashless.

Salah satu pajak yang harus dibayarkan oleh masyarakat sebagai wajib pajak adalah Pajak Bumi dan Bangunan (PBB). PBB merupakan pungutan atas tanah dan bangunan kepada wajib pajak karena telah mempunyai hak serta menerima manfaat atas bumi dan telah mempunyai hak serta menerima manfaat atas bangunan (Waluyo, 2005). Di sisi lain, Badan Keuangan dan Aset Daerah (BKAD) Kabupaten Sleman menyatakan bahwa realisasi PBB di Kabupaten Sleman pada tahun 2019 tidak mencapai target dan mengalami penurunan dibandingkan dengan realisasi PBB pada tahun sebelumnya. Data realisasi pendapatan PBB di Kabupaten Sleman pada tahun 2018 dan tahun 2019 adalah sebagai berikut:

Tabel 1. Realisasi Pajak Bumi dan Bangunan Kabupaten Sleman

\begin{tabular}{ccccc}
\hline Tahun & $\begin{array}{c}\text { Jumlah Ketetapan } \\
\text { SPPT }\end{array}$ & $\begin{array}{c}\text { Ketetapan } \\
\text { (Rp) }\end{array}$ & $\begin{array}{c}\text { Jumlah } \\
\text { Realisasi SPPT }\end{array}$ & $\begin{array}{c}\text { Realisasi } \\
\text { (Rp) }\end{array}$ \\
\hline 2018 & 620.555 & $72 \mathrm{M}$ & 510.509 & $73,6 \mathrm{M}$ \\
\hline 2019 & 627.729 & $83 \mathrm{M}$ & 522.850 & $62,4 \mathrm{M}$ \\
\hline
\end{tabular}

Sumber: Tribunjogja.com (2020)

Terjadinya penurunan realisasi PBB ini tentu saja harus segera diatasi oleh Pemerintah Kabupaten (Pemkab) Sleman. Era revolusi industri 4.0 dan adanya wajib pajak yang merupakan kaum milenial tentunya menjadi pertimbangan bagi pemerintah untuk mengadopsi teknologi sebagai salah satu sarana di dalam pembayaran pajak. Pembayaran pajak secara online telah diterapkan oleh beberapa daerah, antara lain oleh Provinsi DKI Jakarta, Kota Semarang, dan Kabupaten Sleman. Kabupaten Sleman telah menetapkan aplikasi-aplikasi pembayaran PBB secara online, yaitu melalui ATM, Go-Pay, traveloka, tokopedia, dll. Pemkab Sleman telah menggunakan Go-Pay sebagai salah satu alat bagi wajib pajak untuk membayarkan PBB sejak tahun 2019. Pemanfaatan Go-Pay dalam pembayaran online ini tentu saja perlu dievaluasi terkait dengan kemanfaatan dan kemudahannya bagi wajib pajak PBB.

Menurut Adam et.al (1992) sejauh mana kepercayaan setiap individu dalam menggunakan suatu sistem dapat memberi peningkatan pada prestasi kinerjanya disebut sebagai persepsi kemanfaatan Pratama \& Suputra (2019). Bila transaksi pembayaran PBB dilakukan secara manual, maka dapat membuat waktu wajib pajak terbuang sia-sia karena harus mengikuti antrian pelayanan. Go-Pay menawarkan efisiensi dalam pembayaran PBB, karena bisa dilakukan kapan saja dan dimana saja tanpa harus mendatangi kantor pelayanan pajak. Dengan adanya kemanfaatan penggunaan Go-Pay sebagai alat yang digunakan untuk transkasi pembayaran PBB ini, maka diharapkan wajib pajak PBB memiliki kemauan untuk 
terus membayar PBB menggunakan Go-Pay. Penelitian yang menyatakan hal serupa adalah penelitian Joan \& Sitinjak (2019) yang menyatakan bahwa persepsi kemanfaatan memiliki pengaruh positif signifikan terhadap minat penggunaan teknologi. Namun penelitian Danurdoro \& Wulandari (2016) dan Theocharidis et al. (2020) memberikan hasil yang berbeda, yaitu bahwa persepsi kemanfaatan berpengaruh negatif terhadap minat penggunaan sistem. Bukti empiris Sondakh (2017) juga menunjukkan bahwa persepsi kegunaan tidak berpengaruh positif signifikan terhadap niat untuk menggunakan e-SPT.

Persepsi kemudahan didefisinikan oleh Davis (1989) sebagai sejauh mana individu merasakan kemudahan dalam menggunakan teknologi (Ma et al., 2017). Jika pengguna merasakan bahwa Go-Pay mudah dimengerti, dipahami, dan dioperasikan, maka dapat mendorong wajib pajak untuk terus berulang-ulang melakukan transaksi pembayaran PBB menggunakan Go-Pay. Teknologi yang mudah tentu saja dapat dengan mudah dipahami penggunaanya oleh orang yang awam terhadap teknologi, sehingga tidak memerlukan banyak waktu untuk mempelajarinya. Tarhini et al. (2017) memberikan bukti empiris bahwa persepsi kemudahan berpengaruh positif terhadap minat mahasiswa/siswa untuk menggunakan sistem e-learning. Penelitian Joan \& Sitinjak (2019) mengutaran bahwa persepsi kemudahan memiliki pengaruh positif dan signifikan terhadap minat penggunaan teknologi. Bertentangan dengan penelitian Wong et al. (2013) yang membuktikan bahwa persepsi kemudahan berpengaruh negatif terhadap minat penggunaan teknologi.

Penelitian ini bertujuan untuk menguji mengenai minat wajib pajak di Kabupaten Sleman Provinsi Daerah Istimewa Yogyakarta untuk melakukan pembayaran PBB menggunakan Go-Pay. Minat menggunakan Go-Pay pada pembayaran PBB ini belum pernah diteliti sebelumnya karena sistem pembayaran menggunakan Go-Pay baru ditetapkan di Kabupaten Sleman pada tahun 2019. Persepsi kemanfaatan dan persepsi kemudahan diduga sebagai faktor-faktor yang mempengaruhi minat membayar PBB menggunakan Go-Pay.

\section{TINJAUAN PUSTAKA}

\section{Theory of Reasond Action (TRA)}

Ajzen dan Fishbein (1980) mengemukakan TRA dan telah dimodernkan dengan theory of planned behaviour (TPB). TRA mengasumsikan bahwa setiap perilaku dapat ditentukan dari kemauan setiap individu yang mengamalkan atau tidak mengamalkan perilaku tertentu dan kebalikannya. Teori perilaku dikembangkan menjadi TRA dengan menambahkan konstruk membangun suatu perilaku kontrol yang dirasakan. Teori perilaku ini telah dipakai secara ekstensif dalam melakukan dugaan terhadap kemauan saat berperilaku dan perilaku aktual di dalam psikologi (Mahyarni, 2013). Davis (1989) mengemukakan Technology Acceptance Model (TAM) adalah sebuah aplikasi yang diadopsi dari TRA dan dispesialisasikan untuk memodelkan penerimaan terhadap pemakaian sistem informasi. Konstruk-konstruk di dalam TAM ini dapat dipergunakan untuk mengetahui faktor-faktor apa saja yang menyebabkan perilaku masyarakat terhadap pengadopsian teknologi terkait dengan sistem informasi. Penelitian ini 
tidak menggunakan model TAM secara utuh, tetapi mengambil 2 variabel terpenting di dalam TAM saja.

\section{Pajak Bumi dan Bangunan}

Undang-Undang Nomor 28 Tahun 2009 telah disahkan sebagai pengganti Undang-Undang Nomor 18 Tahun 1997. Perubahan Undang-Undang ini merupakan pengalihan Bea Perolehan Hak atas Tanah dan Bangunan (BPHTB) dan Pajak Bumi dan Bangunan Perdesaan dan Perkotaan (PBB-P2) menjadi pajak daerah. Pajak daerah adalah pajak yang dibayarkan masyarakat untuk digunakan sebagai pembiayaan pembangunan daerah (Ismail, 2018). Pajak daerah adalah biaya yang wajib dibayarkan oleh wajib pajak dan dianggap sebagai terutang yang memiliki sifat pemaksaan tanpa menerima imbalan secara langsung dan akan dipakai untuk pembangunan daerah (Wulandari \& Iryanie, 2018). PBB termasuk sumber pemasukan negara yang cukup potensial yang berasal dari pajak daerah. PBB adalah iuran yang ditanggung orang pribadi maupun badan yang mempunyai hak-hak individu atas bumi dan hak-hak individu atas bangunan serta mendapatkan manfaat dari padanya.

\section{Go-Pay di Dalam Pembayaran PBB}

Go-Pay merupakan uang elektronik untuk melakukan pembayaran dan berbagai macam transaksi keuangan yang dapat digunakan melalui aplikasi Gojek (gojek.com). Go-Pay adalah alat yang digunakan untuk pembayaran PBB di Kabupaten Sleman. Go-Pay telah disahkan sebagai salah satu sarana untuk membayarkan PBB sejak 11 September 2019. Pengesahan ini ditandai dengan adanya penenandataganan Memorandum of Understanding (MoU) antara Bank BPD DIY dengan PT Dompet Anak Bangsa sebagai perusahaan yang mengelola Go-Pay tentang kesepakatan mengenai layanan pembayaran tagihan (multibiller) secara online (jogja.tribunnews.com). Pembayaran PBB dapat dilakukan melalui fitur GoBills yang tersedia di aplikasi Gojek.

\section{Persepsi Kemanfaatan}

Persepsi kemanfaatan merupakan suatu tingkatan kepercayaan dimana pengguna suatu sistem memperoleh manfaat dari penggunaan suatu sistem (Agustina, 2015). Persepsi kemanfaatan didefinisikan oleh Davis (1989) sebagai fase kepercayaan individu bahwa ketika mereka menggunakan suatu teknologi atau sistem informasi maka dapat memberikan peningkatan pada kinerja mereka (Laksana, 2015). Variabel persepsi kemanfaatan dapat diukur dengan menggunakan 3 (tiga) indikator, yaitu peningkatan produktivitas kinerja, meningkatkan efektivitas, dan bermanfaat (Andrian et al., 2013). Ketiga inidikator ini dituangkan ke dalam 7 (tujuh) item pernyataan di dalam kuesioner.

\section{Persepsi Kemudahan}

Persepsi kemudahan yang dikemukan oleh Jogiyanto (2007) adalah seberapa besar kepercayaan seseorang bahwa dengan menggunakan suatu teknologi maka orang tersebut dapat terbebas dari suatu usaha (Pratama \& Suputra, 2019). Davis (1989) menyatakan bahwa tingkat kepercayaan pada diri seseorang bahwa dengan menggunakan sistem maka orang yang mengerjakan 
sesuatu dapat mengurangi usahanya disebut sebagai karakteristik kemudahan atau disebut mudah dipahami dan mudah dioperasikan, sehingga pengguna percaya terhadap suatu teknologi informasi (Agustina, 2015). Persepsi kemudahan dapat diukur dengan menggunakan 3 (tiga) indikator, yaitu mudah dipahami dan dioperasikan, serta tidak diperlukan banyak usaha (Andrian et al., 2013). Indikator-indikator ini kemudian dituangkan menjadi 7 (tujuh) pernyataan di kuesioner.

\section{Minat Membayar Pajak Bumi dan Bangunan Menggunakan Go-Pay}

Minat penggunaan adalah minat perilaku pengguna sistem informasi, dimana akan menjadi cenderung dan akan terus berulang menggunakannya (Joan \& Sitinjak, 2019). Dengan demikian, minat membayar PBB melalui Go-Pay adalah niat perilaku wajip pajak untuk terus menerus menggunakan Go-Pay dalam pembayaran PBB. Terdapat 3 (tiga) indikator yang dipakai untuk pengukuran variabel minat membayar PBB menggunakan Go-Pay, yaitu motif sosial yang membangkitkan minat, adanya dorongan dalam diri individu, dan adanya faktor emosional. Ketiga inidikator ini dinyatakan di dalam 3 (tiga) pernyataan di dalam kuesioner.

\section{Pengembangan Hipotesis}

Terdapat enam konstruk di dalam TAM, yaitu perceived usefulness, perceived of use, external variable, attitude toward using, behavioral intention, dan actual use. Keenam konstruk ini menjelaskan bahwa minat (intention) mempengaruhi pengguna sistem informasi, dimana minat tersebut dipengaruhi oleh persepsi tentang kegunaan sistem dan persepsi tentang kemudahan penggunaan teknologi (Kurniawan et al., 2019). Konstruk-kontruk ini digunakan untuk mengetahui tingkat keberterimaan sistem informasi di dalam masyarakat. Persepsi kemudahan dan persepsi kemanfaatan adalah konstruk terpenting di dalam TAM (Fu et al., 2006). Temuan Tarhini et al., (2017) membuktikan bahwa kedua konstruk ini secara langsung mempengaruhi niat penggunaan e-learning. Lebih lanjut, Tarhini et al., (2017) mengemukakan bahwa persepsi kemanfaatan merupakan determinan utama minat di dalam menggunakan e-learning.

Persepsi kemanfaatan yang dirasakan terhadap penggunaan komputer terbukti memiliki pengaruh positif yang signifikan terhadap niat perilaku siswa dan guru untuk menggunakan komputer dalam proses belajar mengajar (Wong et al., 2013). Ali et al. (2018) dan Ching-Ter et al. (2017) memberikan bukti empiris bahwa persepsi kemanfaatan berpengaruh positif terhadap minat mahasiswa/siswa untuk menggunakan sistem e-learning. Hasil penelitian Monica \& Tama (2017) menyatakan bahwa persepsi kemanfaatan memiliki pengaruh positif dan signifikan terhadap minat menggunakan electronic commerce. Penelitian yang dilakukan oleh (Joan \& Sitinjak, 2019) memberikan bukti empiris bahwa persepsi kemanfaatan memiliki pengaruh secara langsung dan positif terhadap minat menggunakan layanan pembayaran digital Go-Pay. Hasil penelitian Pratama \& Suputra (2019) juga menunjukkan bahwa persepsi manfaat bagi pengguna memiliki pengaruh positif terhadap minat dalam penggunaan uang elektronik. Berdasarkan paparan di atas maka hipotesis pertama yang diuji adalah: 


\section{$\mathrm{H}_{1}$ : Persepsi kemanfaatan berpengaruh positif terhadap minat membayar PBB menggunakan Go-Pay}

Persepsi kemudahan dapat didefinisikan sebagai tingkatan kepercayaan seseorang bahwa menggunakan suatu sistem teknologi tertentu akan membebaskan penggunanya dari suatu upaya (Pratama \& Suputra, 2019). Kemudahan akan dirasakan ketika seseorang merasakan upaya atau pengorbanan yang diperlukan dapat diminimalisir dengan adanya teknologi. Tarhini et al., (2017) mengemukakan bahwa persepsi kemudahan merupakan determinan utama minat di dalam menggunakan e-learning. Bukti empiris bahwa persepsi kemudahan berpengaruh positif terhadap minat mahasiswa/siswa untuk menggunakan sistem e-learning juga ditunjukkan oleh Ali et al. (2018) dan ChingTer et al. (2017). Selain itu, penelitian yang dilakukan Joan \& Sitinjak (2019) menunjukkan bahwa persepsi kemudahan memiliki pengaruh positif terhadap minat penggunaan layanan pembayaran digital Go-Pay. Apabila seseorang beranggapan positif terhadap pembayaran menggunakan Go-Pay karena mudah dipahami, mudah dioperasikan dan tidak ada kendala dalam melakukan transaksi, maka orang tersebut akan senang dan berminat untuk melakukan pembayaran menggunakan Go-Pay. Berdasarkan paparan di atas maka hipotesis kedua yang diuji adalah:

$\mathrm{H}_{2}$ : Persepsi kemudahan berpengaruh positif terhadap minat membayar PBB menggunakan Go-Pay

Kerangka pikir dalam pengembangan hipotesis ini dapat digambarkan sebagai berikut:

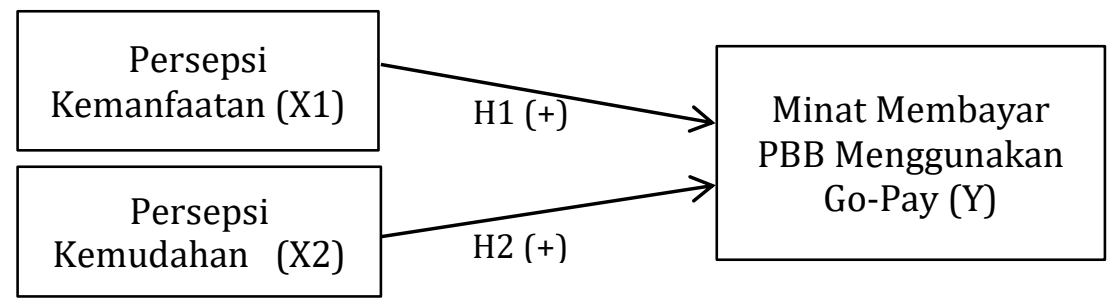

Sumber: Data primer diolah (2020)

Gambar 1. Kerangka Pemikiran

\section{METODOLOGI PENELITIAN}

Populasi dalam penelitian ini merupakan wajib pajak PBB di Kabupaten Sleman, Daerah Istimewa Yogyakarta. Sampel diambil dengan menggunakan teknik covenience sampling. Pada penelitian ini angket dan google form digunakan sebagai alat penyebaran kuisioner dengan mengambil sampel secara bebas oleh peneliti untuk memilih siapa saja yang ditemuinya untuk dijadikan sebagai sampel. Sampel yang dipilih tentunya tetap harus sesuai dengan kriteria, yaitu pengguna 
Go-Pay dan wajib pajak PBB Kabupaten Sleman. Penyebaran kuesioner dilakukan dari tanggal 31 Oktober 2020 sampai dengan 08 November 2020. Sampel yang terkumpul adalah sebanyak 100 responden, namun sampel yang dapat digunakan adalah 87 responden, karena ada 13 responden yang tidak memenuhi kriteria. Selanjutnya data diolah dengan menggunakan software SPSS versi 20.

\section{Teknik Analisis Data}

Ketiga variabel penelitian diukur dengan menggunakan skala Likert, yaitu skor 5 (sangat setuju), 4 (setuju), 3 (netral), 2 (tidak setuju), dan 1 (sangat tidak setuju) untuk pernyataan positif, dan sebaliknya untuk pernyataan negatif. Sebelum dilakukan uji hipotesis, terlebih dahulu dilakukan uji validitas dan reabilitas, serta uji asumsi klasik yang meliputi uji normalitas data, uji multikolinearitas, uji heteroskedostisitas, uji autokorelasi, dan uji linearitas. Validitas butir-butir pernyataan dalam kuesioner dianalisis dengan menggunakan taraf signifikansi 5\%. Uji reliabilitas pada penelitian ini menggunakan teknik Cronbach Alpa yang diukur dengan berdasarkan pada skala Cronbach Alpa 0 sampai 1. Pada penelitian ini, analisis regresi linier berganda digunakan sebagai teknik analisis data untuk menguji hipotesis penelitian. Analisis tersebut digunakan untuk melihat apakah variabel persepsi kemanfaatan dan persepsi kemudahan berpengaruh positif terhadap minat membayar PBB dengan menggunakan Go-Pay.

\section{HASIL DAN PEMBAHASAN}

Berdasarkan data yang didapatkan dari penyebaran kuesioner, berikut adalah karakteristik responden berdasarkan jenis kelamin, pendidikan terakhir, dan umur responden:

Tabel 2. Karakteristik Responden

\begin{tabular}{lccc}
\hline No & Keterangan & Jumlah & Persentase (\%) \\
\hline Panel A. Jenis Kelamin Responden & & \\
1 & Pria & 51 & 60,9 \\
2 & Wanita & 35 & 39,1 \\
& Jumlah & $\mathbf{8 7}$ & $\mathbf{1 0 0}$ \\
\multicolumn{2}{l}{ Panel B. Pendidikan Terakhir Responden } & & \\
1 & SLTA/Sederajat & 32 & 36,8 \\
2 & D1/D2/D3 & 17 & 19,5 \\
3 & S1/S2/S3 & 38 & 43,7 \\
& Jumlah & $\mathbf{8 7}$ & $\mathbf{1 0 0}$ \\
Panel C. Umur Responden & & \\
1 & 20-30 Tahun & 28 & 32,2 \\
2 & 31-40 Tahun & 39 & 44,8 \\
3 & 41-50 Tahun & 20 & 23 \\
4 & Diatas 50 Tahun & 0 & 0 \\
& Jumlah & $\mathbf{8 7}$ & $\mathbf{1 0 0}$ \\
\hline
\end{tabular}

Sumber: Data primer diolah (2020) 
Sebagian besar wajib pajak PBB di Kabupaten Sleman yang menjadi sampel pada penelitian ini adalah pria sejumlah 60,9 persen (51 orang) dari 87 wajib pajak PBB Kabupaten Sleman yang dijadikan sampel. Berdasarkan tingkat pendidikan terakhir, sebanyak 43,7 persen responden pada penelitian ini berpendidikan terakhir S1/S2/S3. Wajib pajak PBB Sleman yang menjadi responden mayoritas berumur 31-40 tahun yaitu sebanyak 44,8 persen. Hal ini menunjukan bahwa mayoritas wajib pajak PBB Sleman tersebut berada pada rentang usia produktif dan merupakan kaum milenial yang terbiasa menggunakan teknologi.

Tabel 3 di bawah ini menunjukkan hasil uji statistik deskriptif terhadap jawaban responden pada setiap variabel.

Tabel 3. Statistik Deskriptif

\begin{tabular}{lcccc} 
& N & Minimum & Maximum & Rata-Rata \\
\hline PM & 87 & 14 & 35 & 30,43 \\
PK & 87 & 12 & 35 & 30,52 \\
MM & 87 & 5 & 15 & 13,36 \\
\hline
\end{tabular}

Sumber: Data primer diolah (2020)

Keterangan:

PM : Persepsi kemanfaatan

PK : Persepsi kemudahan

MM : Minat membayar PBB menggunakan Go-Pay

Nilai maximum jika responden merasa Go-Pay sangat bermanfaat untuk membayarkan PBB adalah 35 (skor 5 untuk masing-masing dari 7 pernyataan). Hasil statistik deskriptif untuk variabel persepsi kemanfaatan menunjukan nilai minumim sebesar 14 , nilai maximum sebesar 35 , dan rata-rata persepsi kemanfaatan sebanyak 30,43. Hal ini dapat dilihat bahwa wajib pajak PBB Sleman memiliki tanggapan yang baik dalam manfaat yang dirasakan. Persepsi kemudahan memiliki nilai minimum sebanyak 12 dan nilai maximum sebanyak 35, serta memiliki nilai rata-rata sebanyak 30,52. Dibandingkan dengan skor maksimum jika responden merasakan bahwa pembayaran PBB sangat mudah, yaitu 35 (skor 5 untuk tiap-tiap dari 7 pernyataan), maka data ini menunjukan bahwa wajib pajak PBB Sleman memiliki tanggapan yang baik dalam kemudahan yang dirasakan. Sedangkan nilai maksimum jika responden merasa sangat berminat untuk membayar PBB menggunakan Go-Pay adalah 15 (skor 5 untuk masing-masing dari 3 pernyataan). Variabel minat membayar PBB menggunakan Go-Pay memiliki nilai minimum adalah 5 , nilai maksimum adalah 15 , dan memiliki nilai rata-rata sebesar 13,36. Dilihat dari skor maksimum jika responden merasa sangat berminat, yaitu 15, maka berdasarkan data tersebut, dalam hal ini keinginan untuk membayar PBB menggunakan Go-Pay, dapat dikatakan tergolong tinggi.

\section{Uji Kualitas Data}

Dalam penelitian ini nilai r-tabel dapat diketahui senilai 0,1755. Penghitungan secara keseluruhan menunjukkan bahwa semua item pernyataan dinyatakan valid karena nilai r-hitung > nilai r-tabel. Pengujian Reliabilitas 
menggunakan Cronbach Alpha menunjukan bahwa variabel persepsi kemanfaatan senilai 0,907, variabel persepsi kemudahan senilai 0,927 , dan variabel minat membayar PBB menggunakan Go-Pay senilai 0,901. Nilai Cronbach Alpha tersebut lebih besar dari nilai $\alpha$ (alpha) 0,60 yang mempunyai arti bahwa item-item pernyataan dinyatakan reliabel. Berdasarkan hasil uji validitas dan reliabilitas ini maka dapat disimpulkan bahwa semua butir pernyataan dapat digunakan sebagai alat dalam pengumpulan data.

\section{Pengujian Hipotesis}

Berikut adalah hasil pengujian hipotesis dengan menggunakan persamaan regresi linier berganda:

Tabel 4. Pengujian Hipotesis

\begin{tabular}{lcc}
\hline \multicolumn{1}{c}{ Variabel } & $\begin{array}{c}\text { Koef. } \\
\text { Regresi }\end{array}$ & Signifikansi \\
\hline Persepsi Kemanfaatan & 0,184 & $0,004^{* * *}$ \\
Persepsi Kemudahan & 0,236 & $0,000^{* * *}$ \\
\hline
\end{tabular}

Sumber: Data primer diolah (2020)

Keterangan: *,**,***: signifikan pada level $\alpha 10 \%, 5 \%, 1 \%$.

Berdasarkan Tabel 4, nilai signifikansi variabel persepsi kemanfaatan sebesar $0,004<0,05$ (sig. $\mathrm{t}<\alpha$ ) dan dapat dilihat dari nilai koefisien regresi positif sebesar 0,184. Dapat disimpulkan bahwa persepsi kemudahan memiliki pengaruh positif signifikan terhadap minat membayar PBB menggunakan Go-Pay. Dengan demikian hipotesis pertama dalam penelitian ini dinyatakan didukung. Nilai signifikansi variabel persepsi kemudahan sebesar 0,000 0,05 (sig. $\mathrm{t}<\alpha$ ) dan nilai koefisien regresi positif 0,236. Dapat disimpulkan bahwa persepsi kemudahan berpengaruh positif signifikan terhadap minat membayar PBB menggunakan GoPay atau dengan kata lain bahwa hipotesis kedua dinyatakan didukung.

\section{Persepsi Kemanfaatan Terhadap Minat Membayar PBB Menggunakan Go-Pay}

Hasil uji hipotesis yang telah dilakukan menunjukkan bahwa hipotesis pertama $\left(\mathrm{H}_{1}\right)$ yang menyatakan persepsi kemanfaatan memiliki pengaruh positif signifikan terhadap minat membayar PBB menggunakan Go-Pay didukung. Hal tersebut terbukti dari hasil uji r-hitung sebanyak 1 lebih besar dari r-tabel sebanyak 0,1755 dengan nilai signifikansinya sebanyak 0,004 lebih kecil dari 0,05 dan nilai Unstandardized Coefficients B sebesar 0.184. Dengan demikian dapat disimpulkan bahwa semakin tinggi tingkat kemanfaatan yang dirasakan oleh wajib pajak maka semakin tinggi pula kemauan wajib pajak untuk menggunakan Go-Pay di dalam pembayaran PBB. Di samping itu, wajib pajak juga merasakan bahwa pembayaran PBB melalui Go-Pay memberikan manfaat yang cukup besar. Pendapat ini berdasarkan pada hasil analisis jawaban responden yang mempunyai nilai rata-rata 30,43 (dengan nilai maksimum 35) pada variabel kemanfaatan atas layanan Go-Pay di dalam pembayaran PBB. Ini dapat dikatakan bahwa wajib pajak merasakan kemanfaatan atas layanan Go-Pay dan berkeinginan untuk terus membayarkan PBB menggunakan Go-Pay. Manfaat ini terutama dirasakan oleh responden yang bekerja di kantor karena mereka tidak perlu mengajukan ijin, 
kemudian pergi untuk membayar dan mengantri untuk membayar PBB. Para responden juga merasakan bahwa penggunaan Go-Pay dapat memotong alur pembayaran menjadi lebih ringkas dan efektif. Hasil penelitian ini mendukung hasil penelitian Monica \& Tama (2017), Joan dan Sitinjak (2019), dan Pratama \& Suputra (2019) yang mengungkapkan bahwa persepsi kemanfaatan mempunyai pengaruh positif terhadap minat penggunaan. Hasil penelitian ini berbeda dengan hasil penelitian Danurdoro, K., \& Wulandari, D. (2016) karena penelitian tersebut menggunakan internet banking dengan responden mahasiswa, hasil penelitiannya menunjukkan bahwa transaksi internet banking dipandang kurang bermanfaat bagi mahasiswa karena merupakan transaksi non-cash sementara mahasiswa lebih cenderung banyak memanfaatkan transaksi cash. Sedangkan dalam penelitian ini responden menggunakan transaksi non-cash dalam pembayaran PBB yaitu melalui aplikasi Go-Pay.

\section{Persepsi Kemudahan Terhadap Minat Membayar PBB Menggunakan Go-Pay}

Hipotesis kedua $\left(\mathrm{H}_{2}\right)$ pada penelitian ini yang menyatakan bahwa persepsi kemudahan berpengaruh positif terhadap minat membayar PBB menggunakan GoPay dinyatakan didukung. Hasil uji hipotesis menunjukkan bahwa r-hitung sebesar 1 yang mana lebih besar dari r-tabel yang sebesar 0,1755 , dan dengan nilai signifikansinya sebesar 0,000 lebih kecil dari 0,05, serta nilai Unstandardized Coefficients B sebesar 0.236. Hal tersebut berarti bahwa semakin tinggi tingkat kemudahan yang dirasakan wajib pajak maka semakin tinggi pula minat wajib pajak untuk membayarkan PBB menggunakan Go-Pay. Selain itu, wajib pajak juga merasakan bahwa Go-Pay memberikan kemudahan di dalam pembayaran PBB. Pendapat ini berdasarkan pada hasil analisis jawaban responden pada variabel persepsi kemudahan yang mempunyai nilai rata-rata 30,52 (dari nilai maksimum 35). Mayoritas responden merasakan kemudahan dengan adanya Go-Pay karena bisa membayarkan PBB kapan saja dan dimana saja. Responden juga tidak merasakan kesulitan dalam melakukan pembayaran karena aplikasi Go-Pay mudah dipahami. Dalam diri wajib pajak yang merasakan kemudahan atas layanan Go-Pay akan timbul rasa ketertarikan untuk kembali melakukan pembayaran PBB menggunakan Go-Pay. Hasil penelitian ini mendukung penelitian yang dilakukan oleh Rusfianto et al. (2016) dan Joan \& Sitinjak (2019) yang menyatakan bahwa persepsi kemudahan berpengaruh positif dan signifikan terhadap minat penggunaan. Penelitian ini berbeda dengan hasil penelitian Wong (2013) karena penelitian Wong tersebut menggunakan responden yang sudah mempunyai pengetahuan kompleks dengan program komputer seperti misalnya Web 2.0, Gapminder World, Google sketchup, dan lainnya. Responden pada penelitian Wong (2013) lebih menginginkan tantangan terhadap perancangan dan penggunaan aplikasi, sedangkan pada penelitian ini menggunakan responden masyarakat umum yang belum tentu mempunyai pengetahuan kompleks terhadap aplikasi komputer. 


\section{SIMPULAN}

Berdasarkan hasil penelitian ini dapat disimpulkan bahwa persepsi kemanfaatan dan persepsi kemudahan memiliki pengaruh positif signifikan terhadap minat wajib pajak di dalam membayar PBB menggunakan Go-Pay di Kabupaten Sleman. Mayoritas wajib pajak yang menjadi sampel adalah wajib pajak yang masih berusia muda, yaitu 31-40 tahun sebanyak 39 persen dan 20-30 tahun sebanyak 28 persen. Wajib pajak yang termasuk dalam kisaran usia tersebut merupakan wajib pajak yang masih produktif dan merupakan generasi milenial yang familier dengan internet. Ericsson mencatat, produk teknologi akan mengikuti gaya hidup masyarakat millennial (www.Kominfo.go.id). Oleh karena itu, wajar jika mayoritas responden memilih menggunakan aplikasi Go-Pay daripada membayarkan PBB secara langsung ke BKAD. Lebih dari itu, responden juga merasakan bahwa Go-Pay dapat memudahkan dan bermanfaat bagi mereka sebagai wajib pajak untuk membayarkan PBB.

Manfaat yang dirasakan wajib pajak tersebut antara lain dapat memotong alur pembayaran PBB sehingga menjadi lebih cepat, dapat meminimalkan biaya perjalanan, mengurangi antrian saat pembayaran, dan dapat dibayarkan kapan saja. Wajib pajak juga merasakan kemudahan penggunaan Go-Pay dalam pembayaran PBB karena aplikasinya mudah dipahami, mudah diakses, tidak memerlukan banyak waktu untuk menggunakan aplikasinya, dan dapat melakukan pembayaran dimana saja. Wajib pajak yang membayar PBB menggunakan Go-Pay merasakan bahwa pembayaran PBB menggunakan Go-Pay bermanfaat dan memudahkan, sehingga minat mereka untuk menggunakan Go-Pay untuk membayarkan PBB tinggi. Semakin tinggi tingkat persepsi kegunaan dari penggunaan Go-Pay akan membuat wajib pajak beranggapan bahwa Go-Pay dapat meningkatkan efisiensi dan kenyamanan dalam pembayaran PBB. Di sisi lain, kemudahan dan ketepatan waktu yang dihadirkan oleh penggunaan Go-Pay akan meningkatkan persepsi wajib pajak terhadap efisiensi pembayaran PBB. Wajib pajak kemudian akan semakin berminat untuk membayar PBB dengan menggunakan Go-Pay. Hasil penelitian ini sejalan dengan bukti empiris yang dikemukakan oleh Ali et al. (2018) dan (Ching-Ter et al., 2017) yang menunjukkan bahwa konstruksi kunci TAM, yaitu persepsi kemanfaatan dan persepsi kemudahan, berpengaruh positif terhadap minat mahasiswa/siswa untuk menggunakan sistem e-learning.

\section{Saran}

Diharapkan Badan Keuangan Aset Daerah (BKAD) Sleman dapat terus memberikan pemahaman kepada wajib pajak agar melakukan pembayaran PBB secara online yang salah satunya melalui Go-Pay. Dengan demikian antrian pelayanan pada BKAD Sleman dapat diminimalisir. Sedangkan dari sudut wajib pajak, diharapkan wajib pajak dapat menggunakan layanan Go-Pay dalam pembayaran PBB agar tidak perlu lama menunggu antrian di pelayanan BKAD Sleman, sehingga dapat melakukan kegiatan lainnya yang lebih produktif. Pemerintah Kabupaten, dalam hal ini BKAD Kabupaten Sleman, tentu saja harus terus berupaya untuk meningkatkan kebermanfaatan dan kemudahan penggunaan 
sistem pembayaran PBB secara online agar menjadi semakin ramah pengguna dan fungsional.

Penelitian ini memberikan implikasi kepada Pemerintah Kabupaten bagaimana wajib pajak PBB di Kabupaten Sleman dapat beradaptasi dengan GoPay sebagai salah satu sarana untuk membayarkan PBB. Penelitian ini dapat dilanjutkan dengan melakukan evaluasi terhadap efektivitas pengadopsian Go-Pay di dalam meningkatkan realisasi PBB. Hendaknya peneliti selanjutnya dapat menambah dan memperluas sampel penelitian, tidak hanya pada satu Kabupaten Sleman tetapi berbagai daerah, baik daerah yang sudah menggunakan layanan GoPay untuk pembayaran PBB maupun yang belum menggunakan Go-Pay. Penelitian ini juga dapat dikembangkan dengan menggunakan variabel lain terkait dengan fasilitas pembayaran pajak online selain Go-Pay. Penelitian ini diperlukan sebagai bahan kajian mengenai tingkat keberterimaan wajib pajak terhadap teknologi yang diadopsi oleh Pemerintah Daerah (Pemda) dan sebagai upaya bagi Pemda dalam upaya untuk menaikkan tingkat realisasi penerimaan pajak. Penelitian selanjutnya juga dapat dilakukan dengan menggunakan model TAM secara utuh.

\section{DAFTAR PUSTAKA}

Agustina, E. (2015). Pengaruh Kepercayaan, Persepsi Kegunaan, Persepsi Kemudahan Penggunaan terhadap Sikap Pengguna. 1-13.

Ali, M., Ali Raza, S., Qazi, W., \& Puah, C.-H. (2018). Interactive Technology and Smart Education Assessing the e-learning system in higher education institutes: evidence from structural equation modelling Article information: For Authors Assessing e-learning system in higher education institutes: evidence fr. Interactive Technology and Smart Education, 15(1), 59-78. https://doi.org/10.1108/ITSE-02-2017-0012

Andrian, A., Kertahadi, \& Susilo, H. (2013). Analisis Pengaruh Persepsi Kegunaan, Persepsi Kemudahan, Dan Sikap Penggunaan Terhadap Minat Perilaku Penggunaan Billing System. Journal of Chemical Information and Modeling, 53(9), 1689-1699. https://doi.org/10.1017/CB09781107415324.004

Ching-Ter, C., Hajiyev, J., \& Su, C. R. (2017). Examining the students' behavioral intention to use e-learning in Azerbaijan? The General Extended Technology Acceptance Model for E-learning approach. Computers and Education, 111, 128-143. https://doi.org/10.1016/j.compedu.2017.04.010

Danurdoro, K., \& Wulandari, D. (2016). The Impact of Perceived Usefulness, Perceived Ease of Use, Subjective Norm, and Experience Toward Student's Intention to Use Internet Banking. Jurnal Ekonomi Dan Ekonomi Studi Pembangunan, 8(1), 17-22. https://doi.org/10.17977/um002v8i12016p017

Fu, J. R., Farn, C. K., \& Chao, W. P. (2006). Acceptance of electronic tax filing: A study of taxpayer intentions. Information and Management, 43(1), 109-126. https://doi.org/10.1016/j.im.2005.04.001

https://www.kominfo.go.id/content/detail/8566/mengenal-generasi millennial/0/sorotan_media

Ismail, T. (2018). Potret Pajak Daerah Di Indonesia. Kencana. 
Joan, L., \& Sitinjak, T. (2019). Pengaruh Persepsi Kebermanfaatan Dan Persepsi Kemudahan Penggunaan Terhadap Minat Penggunaan Layanan Pembayaran Digital Go-Pay. Jurnal Manajemen, 8(2), 27-39.

Kurniawan, T. A., Wardani, D. K., \& Widhayati, L. (2019). Pengaruh Keberterimaan Layanan Peer to Peer Lending Kepada Umkm Sebagai Pengguna Dengan Menggunakan Metode Technology Acceptance Model (TAM). Jurnal Sosial Ekonomi Dan Humaniora (JSEH), 5, 151-160.

Laksana, G. B. (2015). Pengaruh Persepsi Kemanfaatan, Persepsi Kemudahan Penggunaan, Persepsi Resiko Dan Persepsi Kesesuaian Terhadap Minat Menggunakan Mobile Banking (Studi Pada Nasabah Bank Rakyat Indonesia (Bri) Kantor Cabang Rembang, Jawa Tengah). Jurnal Administrasi Bisnis, 26(2), 1-8.

Ma, Y. J., Gam, H. J., \& Banning, J. (2017). Perceived ease of use and usefulness of sustainability labels on apparel products: application of the technology acceptance model. Fashion and Textiles, 4(1), 1-20. https://doi.org/10.1186/s40691-017-0093-1

Mahyarni, M. (2013). Theory Of Reasoned Action Dan Theory Of Planned Behavior (Sebuah Kajian Historis tentang Perilaku). Jurnal EL-RIYASAH, 4(1), 13. https://doi.org/10.24014/jel.v4i1.17

Monica, N., \& Tama, annafi indra. (2017). Pengaruh Persepsi Manfaat, Persepsi Kemudahan, Persepsi Kenyamanan, Norma Subjektif dan Kepercayaan Terhadap Minat Menggunakan Elektronik Commerce. JRAK Vol.8 No.1 Februari 2017, 8(April), 27-41.

Pratama, A. B., \& Suputra, I. D. G. D. (2019). Pengaruh Persepsi Manfaat, Persepsi Kemudahan Penggunaan, dan Tingkat Kepercayaan Pada Minat Menggunakan Uang Elektronik. E-Jurnal Akuntansi, 27, 927. https://doi.org/10.24843/eja.2019.v27.i02.p04

Rusfianto, M., Widiartanto, \& Prabawani, B. (2016). Pengaruh Persepsi Manfaat, Kemudahan Penggunaan, Dan Kepercayaan Terhadap Sikap Penggunaan Layanan Internet Banking (Studi Komparasi Pada Nasabah Pengguna Internet Banking Bank Mandiri Semarang Berdasarkan Tingkat Pendapatan). 1989.

https://ejournal3.undip.ac.id/index.php/jiab/article/viewFile/11315/109 72

Sondakh, J. J. (2017). Behavioral intention to use e-tax service system: An application of technology acceptance model. European Research Studies Journal, 20(2), 48-64.

Tarhini, A., Hone, K., Liu, X., \& Tarhini, T. (2017). Examining the moderating effect of individual-level cultural values on users' acceptance of E-learning in developing countries: a structural equation modeling of an extended technology acceptance model. Interactive Learning Environments, 25(3), 306-328. https://doi.org/10.1080/10494820.2015.1122635

Theocharidis, A. I., Argyropoulou, M., Karavasilis, G., Vrana, V., \& Kehris, E. (2020). An approach towards investigating factors affecting intention to book a hotel room through social media. Sustainability (Switzerland), 12(21), 1-20. https://doi.org/10.3390/su12218973

Undang-Undang Nomor 28 Tahun 2009 Tentang Pajak Daerah dan Retribusi 


\section{Daerah}

Waluyo. (2005). Perpajakan Indonesia. Salemba Empat.

Wong, K. T., bt Osman, R., Goh, P. S. C., \& Rahmat, M. K. (2013). Understanding student teachers' behavioural intention to use technology: Technology acceptance model (TAM) validation and testing. International Journal of Instruction, 6(1), 89-104.

Wulandari, P. A., \& Iryanie, emy. (2018). Pajak Daerah Dalam Pendapatan Asli Daerah. Deepublish.

www.gojek.com

www. jogja.tribunnews.com 